\title{
Political Connections, Local Interests and Environmental Performance
}

\author{
Sheng Yao, Haotian Liang \\ School of Management, China University of Mining and Technology, Xuzhou, China \\ Email: kj9704@126.com, lianghaotian1989@163.com
}

Received 15 June 2014; revised 22 July 2014; accepted 5 August 2014

Copyright (C) 2014 by authors and Scientific Research Publishing Inc.

This work is licensed under the Creative Commons Attribution International License (CC BY). http://creativecommons.org/licenses/by/4.0/

(c) (†) Open Access

\begin{abstract}
Though there are studies on the relation between political connections and financial performance in the current literature, few have addressed the issue of political connections within the context of the environment. Thus, the goal of this study was to prove, in theory, that political connections and local interests negatively affect the environmental performance in the short and long run under the conditions faced by China.
\end{abstract}

\section{Keywords}

\section{Local Government, Political Connections, Environmental Performance}

\section{Introduction}

Over the past 30 years, local governments have played an important role in the growth of local economies, although it is rare in the world that local governments' passion is to seek financial sources and promote economic development (Lian Zhou [1]). The incentive for political competition greatly promotes regional economic growth, but local governments may loosen environmental regulations for firms that play important roles in local economies when faced with the political demands of local government officials and regional competition. To a certain extent, if an economy is highly dependent on regulated firms, the corresponding local government will not usually tend to increase their operating cost (Yufang Li [2]). It is still debated whether or not governmental regulation is captured within the context of the environment. Some researchers believe that the main purpose of environmental regulation by governments is to correct the externalities caused by environmental pollution; thus, local governments cannot be considered special interest groups. In contrast, other researchers hold the view that the effect of interest groups within the context of the environment is clear, such as through economic regulation. Based on this view, local governments and regulated firms can reach a balance before environmental catastrophes occur. However, such a balance may itself lead to severe environmental events. Since the "Zijin Mining 
Event" in 2010, the complex political relations behind this event have been criticized, and it is believed that there are undeniable relations between environmental events and firms' political connections. However, is the "Zijin Mining Event" a single case or a common phenomenon? If it is a common phenomenon, two questions should be answered. First, how do political connections and local government interests influence environmental performance? Secondly, can empirical data prove that political connections and local interests induce unfavorable effects on environmental performance?

Local government has been an important body in environmental regulation since the 1980s, whose effects directly determine the quality of the national environmental (Hongli Li [3]). However, under the premise that the government is captured within the context of environmental regulation, the government functions as a "helping hand". Its purpose is not to maximize social welfare but usually to promote political interests (Zhonghua Zhang [4]). Thus, local governments that would like to help firms and politically connected firms that would like to receive help can reach a political balance. However, the political balance is not a Pareto balance (Yaodong Zhou [5]), and it comes at the expense of the common people's basic right to life and may lead to severe environmental events. Most of the empirical research has mainly focused on the relationship between political connections and financial performance (or company value) and has found that political connections can improve firms' financial performance or value (Roberts [6]; Fisman [7]; Hellman [8]; Johnson and Mitton [9]; Faccio [10]; Goldman [11]; Claessens [12]; Dombrovsky [13]; Hongbo Pan [14]). Other studies argue that political connections can help firms gain better financial treatment (Sapienza [15]; Khwaja and Mian [16]; Dinc [17]; Fan et al. [18]; Xuyang Hu [19]; Boubakri et al. [20]). However, there are some studies that suggest that political connections also have negative effects on firms (Dewenter and Malatesta [21]; Chen et al. [22]; Bertrand et al. [23]; Chang and Wong [24]; Cheung et al. [25]; Aggarwal et al. [26]; Ball et al. [27]). Moreover, Wengfeng Wu et al. [28] believe that whether or not a firm's value is improved is determined by its ownership. Political connections can improve a private firms' value but cannot benefit the value of locally owned firms. In summary, literatures have scarcely addressed the relationship between political connections and environmental performance. China has passed increasingly stringent environmental regulations, but the environmental quality of the region has only continued to deteriorate. One of reasons for this phenomenon is the negative effect of political connections. Therefore, it is important to study how political connections influence environmental performance by considering local interests to improve the effect of environmental regulation and optimize the regulatory system.

\section{Theoretical Analysis}

\subsection{Revenue Function of Local Governments and Firms}

\subsubsection{Local Government's Revenue Function}

Suppose that an administrative region has a local government and $N$ polluting firms (not including others). The firms' return on equity is represented by $K(t)$, and $t$ is a random variable indicating time. The local government provides the firms with two services; one is public goods $h(t)$ and the other is the excellent quality of the environment $E(t)$.

Based on these parameters, the firms' output (or taxable income) is as follows.

$$
Y(h(t), K(t), E(t))=h(t)^{\alpha} K(t)^{\beta} E(t)^{\gamma}
$$

where $\alpha>0, \beta>0, \gamma>0$ and $\alpha+\beta+\gamma=1$.

If a fixed rate $v$ is set by the central government, the total taxing revenue is $v h(t)^{\alpha} K(t)^{\beta} E(t)^{\gamma}$. The central and local governments share the total tax income, where the central government receives $\theta$ and the local government receives $1-\theta$. The local government receives tax revenues and, at the same time, plays the roles of a helping hand and a grabbing hand. The helping hand refers to the various ways in which the local government supports firms, including tax breaks, convenient financing, loosened environmental regulations, etc. It is denoted by $h(t)+E(t)$. Local governments obtain extra-budgetary revenue by charging and accepting donations from firms, which is what is referred to as the grabbing hand role and denoted by $g(t)$. The local government must pay the price for implementing its grabbing hand role; the price depends on the size of $g(t)$, i.e., $C(g(t))$. Thus, net income $R(t)$, which the local authority obtains at time $t$, is expressed as follows.

$$
R(t)=(1-\theta) v h(t)^{\alpha} K(t)^{\beta} E(t)^{\gamma}-h(t)-E(t)+g(t)-C(g(t))
$$


For simplicity, it is assumed that $C(g(t))$ and $g(t)$ are quadratically related:

$$
C(g(t))=\varepsilon g(t)+\frac{1}{2} \chi g(t)^{2}
$$

The two parameters $\varepsilon$ and $\chi$ represent the degree to which the local government lacks transparency.

\subsubsection{Firms' Revenue Function}

Polluting firms often establish political connections with local governments to avoid local environmental regulation. The ways in which political connections are forged have changed from direct political donations to hiring retired and resigned political officials as senior managers. Through their political resources, firms can influence local governments' decision-making and policy-making and benefit from it. If the political cost is denoted $P(t)$ at time $t$, then the corresponding gain $F(t)$, the net income of the firm, is

$$
F(t)=\frac{1}{N} h(t)^{\alpha} K(t)^{\beta} E(t)^{\gamma}+f(t)-P(t)^{1}
$$

It is noted that $P(t)$ is an active variable controlled by the firms; it affects the quality of the firm's environment $E(t)$ and local government revenue $g(t)$. It can influence the profits $f(t)$ of the firms with political connections based on the local government's reaction.

\subsection{Short-Term Equilibrium without Environmental Incident}

If no environmental incident occurs, profit maximization will be the pursuit of local governments and firms according to their respective revenue functions.

For firms, to make marginal revenue equal to marginal cost, we take the first derivative of function (4) and set it equal to 0 .

$$
F^{\prime}(t)=\frac{1}{N}\left(\alpha h(t)^{\alpha-1} K(t)^{\beta} E(t)^{\gamma}+\beta h(t)^{\alpha} K(t)^{\beta-1} E(t)^{\gamma}+\gamma h(t)^{\alpha} K(t)^{\beta} E(t)^{\gamma-1}\right)+f^{\prime}(t)-P^{\prime}(t)=0
$$

That is,

$$
P^{\prime}(t)=\frac{1}{N}\left(\alpha h(t)^{\alpha-1} K(t)^{\beta} E(t)^{\gamma}+\beta h(t)^{\alpha} K(t)^{\beta-1} E(t)^{\gamma}+\gamma h(t)^{\alpha} K(t)^{\beta} E(t)^{\gamma-1}\right)+f^{\prime}(t)
$$

According to the result of function (6), the prerequisite for forging political connections with governments is that firms' marginal income is able to compensate for the marginal cost of political connections such that it can maximize the firms' profits.

In the short term, local governments also need to consider maximizing their benefits. Although $P(t)$ is the firms' active variable, local governments need to control it based on their own interests to maximize the revenue of local governments. Therefore, function (4) becomes

$$
h(t)^{\alpha} K(t)^{\beta} E(t)^{\gamma}=N(F(t)+P(t)-f(t))
$$

Function (7) and (3) are substituted into (2) to yield

$$
R(t)=N v(1-\theta)(F(t)+P(t)-f(t))-h(t)-E(t)+(1-\varepsilon) g(t)-\frac{1}{2} \chi g(t)^{2}
$$

Taking the first derivative of function (8) and setting it equal 0 yields

$$
R^{\prime}(t)=N v(1-\theta)\left(F^{\prime}(t)+P^{\prime}(t)-f^{\prime}(t)\right)-h^{\prime}(t)-E^{\prime}(t)+(1-\varepsilon-\chi) g^{\prime}(t)=0
$$

Without environmental incidents, local governments and firms maximize their interests; that is,

$$
\begin{gathered}
R^{\prime}(t)=F^{\prime}(t)=0 \\
\frac{1}{N}\left(\alpha h(t)^{\alpha-1} K(t)^{\beta} E(t)^{\gamma}+\beta h(t)^{\alpha} K(t)^{\beta-1} E(t)^{\gamma}+\gamma h(t)^{\alpha} K(t)^{\beta} E(t)^{\gamma-1}\right)+f^{\prime}(t)-P^{\prime}(t) \\
=N v(1-\theta)\left(P^{\prime}(t)-f^{\prime}(t)\right)-h^{\prime}(t)-E^{\prime}(t)+(1-\varepsilon-\chi) g^{\prime}(t)
\end{gathered}
$$

\footnotetext{
${ }^{1}$ Assuming that the income of each firm is equal, its coefficient is determined by the proportion of income in practice.
} 


$$
\begin{aligned}
& P^{\prime}(t) \\
& =\frac{\left(\alpha h(t)^{\alpha-1} K(t)^{\beta} E(t)^{\gamma}+\beta h(t)^{\alpha} K(t)^{\beta-1} E(t)^{\gamma}+\gamma h(t)^{\alpha} K(t)^{\beta} E(t)^{\gamma-1}+\left(N^{2} v(1-\theta)+N\right) f^{\prime}(t)+N h^{\prime}(t)+N E^{\prime}(t)-(1-\varepsilon-\chi) N g^{\prime}(t)\right)}{N^{2} v(1-\theta)+N}
\end{aligned}
$$

Thus, the political connections function $P(t)$ becomes

$$
\begin{aligned}
& P(t) \\
= & \int \frac{\left(\alpha h(t)^{\alpha-1} K(t)^{\beta} E(t)^{\gamma}+\beta h(t)^{\alpha} K(t)^{\beta-1} E(t)^{\gamma}+\gamma h(t)^{\alpha} K(t)^{\beta} E(t)^{\gamma-1}+\left(N^{2} v(1-\theta)+N\right) f^{\prime}(t)+N h^{\prime}(t)+N E^{\prime}(t)-(1-\varepsilon-\chi) N g^{\prime}(t)\right)}{N^{2} v(1-\theta)+N} \mathrm{~d} t+c
\end{aligned}
$$

In the equilibrium state, the local environmental performance $E P$ is

$$
E P=\frac{E(t)}{K(t)}
$$

The change in environmental performance is

$$
E P^{\prime}=\frac{E^{\prime}(t)}{K(t)}-\frac{E(t)}{K^{2}(t)} K^{\prime}(t)=\frac{(E(t) K(t))^{\prime}}{K^{2}(t)}
$$

$E P^{\prime}$ depends on $(E(t) K(t))^{\prime}$. To obtain $(E(t) K(t))^{\prime}$, we must change function (7). Because $\alpha>0$, $\beta>0, \gamma>0$ and $\alpha+\beta+\gamma=1$, we obtain

$$
\begin{aligned}
& h(t)^{\alpha} K(t)^{\beta} E(t)^{\gamma}>(h(t) K(t) E(t))^{\alpha} \\
& (h(t) K(t) E(t))^{\alpha}<N(F(t)+P(t)-f(t)) \\
& K(t) E(t)<\frac{(N(F(t)+P(t)-f(t)))^{-\alpha}}{h(t)}
\end{aligned}
$$

Taking the first derivative of $\frac{(N(F(t)+P(t)-f(t)))^{-\alpha}}{h(t)}$, we obtain

$$
\begin{aligned}
& (K(t) E(t))^{\prime} \\
& \quad<\frac{-\alpha(N(F(t)+P(t)-f(t)))^{-\alpha-1} \times N\left(F^{\prime}(t)+P^{\prime}(t)-f^{\prime}(t)\right) h(t)+h^{\prime}(t)(N(F(t)+P(t)-f(t)))^{-\alpha}}{h^{2}(t)}
\end{aligned}
$$

At equilibrium, $P^{\prime}(t)=f^{\prime}(t)$ and $N(F(t)+P(t)-f(t))>1$; thus, function (16) can be simplified to

$$
(K(t) E(t))^{\prime}<\frac{-\alpha N F^{\prime}(t) h(t)+h^{\prime}(t)}{h^{2}(t)}
$$

Usually, the growth of public goods is less than the base amount, i.e., $h^{\prime}(t)<h(t)$; thus, $(K(t) E(t))^{\prime}<0$. Therefore, environmental performance deteriorates at equilibrium, and this equilibrium is not conducive to the improvement of local environmental quality.

\subsection{Short-Term Equilibrium with Environmental Incident}

Once environmental incidents occur, especially significant environmental events, the short-term equilibrium is broken. Under the investigation of the central government, local governments will increase their environmental inputs. Moreover, the degree of supervision over subsidiary firms will also be enhanced. Simultaneously, other 
incomes besides the tax revenue gained from firms also become 0 . In addition, the central government will deliver punishment to the local government for its connivance regarding environmental regulation. Theoretically, the punishment cost should be a quadratic function of the amount by which environmental quality is reduced; thus, the revenue function of the local government is

$$
\begin{array}{r}
R(t)=(1-\theta) v h(t)^{\alpha} K(t)^{\beta} E(t)^{\gamma}-h(t)-E(t)-C\left(E^{\prime}(t)\right) \\
\text { And: } C\left(E^{\prime}(t)\right)=\varepsilon E^{\prime}(t)+\frac{1}{2} \chi E^{\prime}(t)^{2}
\end{array}
$$

By substituting function (19) into (18), the function of local government income is

$$
R(t)=(1-\theta) v h(t)^{\alpha} K(t)^{\beta} E(t)^{\gamma}-h(t)-E(t)-\varepsilon E^{\prime}(t)-\frac{1}{2} \chi E^{\prime}(t)^{2}
$$

After environmental events occur, the revenue function of firms will change. On the one hand, because the control of the local government will have been strengthened, firms will have to pay the political costs associated with the costs of environmental control and punishment fines. On the other hand, the firms should bear the cost of political connections to support established political connections.

$$
\begin{array}{r}
F(t)=\frac{1}{N} h(t)^{\alpha} K(t)^{\beta} E(t)^{\gamma}-P(t)-C(P(t)) \\
\text { and } C(P(t))=\varepsilon P(t)+\frac{1}{2} \chi P(t)^{2} \\
\text { Thus, } F(t)=\frac{1}{N} h(t)^{\alpha} K(t)^{\beta} E(t)^{\gamma}-(1+\varepsilon) P(t)-\frac{1}{2} \chi P(t)^{2}
\end{array}
$$

After environmental events, local government and firms are in a state of imbalance. Because the local government is in control, the political relations that firms have established are unable to function.

Over time, however, the impact of environmental events gradually decreases. Firms strive to gradually reduce their environmental costs by forging political connections, and the local government bears the firms' environmental costs because it moves down the environmental events spiral. Thus, the equilibrium state is that in which the marginal transferring cost of the firms is equal to the marginal cost of the local government during this period:

$$
\left[h(t)+E(t)+\varepsilon E^{\prime}(t)+\frac{1}{2} \chi E^{\prime}(t)^{2}\right]^{\prime}=\left[(1+\varepsilon) P(t)+\frac{1}{2} \chi P(t)^{2}\right]^{\prime}
$$

By simplifying, we obtain

$$
(1+\varepsilon) P^{\prime}(t)+\chi P(t)=h^{\prime}(t)+(1+\varepsilon) E^{\prime}(t)+\varepsilon E^{\prime \prime}(t)
$$

$P(t)$ can be expressed as follows:

$$
P(t)=\mathrm{e}^{-\frac{\chi}{1+\varepsilon} t}\left(\int \frac{h^{\prime}(t)+(1+\varepsilon) E^{\prime}(t)+\varepsilon E^{\prime \prime}(t)}{1+\varepsilon} \cdot \mathrm{e}^{-\frac{\chi}{1+\varepsilon} t} \mathrm{~d} t\right)+C
$$

At this point, the quality of the environment is considered to be the lowest. However, the firms also need to maintain Formula (26) as the size of $P(t)$ to expect that the environmental impact of an incident is reduced and return to the short-term equilibrium without an environmental incident occurring.

\subsection{Long-Term Equilibrium}

Assume that the tenure of a local government is a random variable $T$. After the government's term ends, the value of the public goods that the local government obtained is $S(K(T))$; therefore, the present value of the local government's income is

$$
V=\int_{0}^{T} R(t) \mathrm{e}^{-\rho t} \mathrm{~d} t+\mathrm{e}^{-\rho T} S(K(T))
$$


If the local government can continue to function under optimal decision-making over a short period, the increase in income over one year is equal to the increase in costs in time $T$. Thus, the income of the local government only includes tax revenue.

$$
R(t)=(1-\theta) v h(t)^{\alpha} K(t)^{\beta} E(t)^{\gamma}
$$

The present value of the local government's income during its tenure is

$$
V=\int_{0}^{T}(1-\theta) v h(t)^{\alpha} K(t)^{\beta} E(t)^{\gamma} \mathrm{e}^{-\rho t} \mathrm{~d} t+\mathrm{e}^{-\rho T} S(K(T))
$$

However, due to environmental events, achieving the optimal income every year is unlikely for local governments. Once an environmental event occurs, the local government must pay an additional cost to reduce the effects of the event, and some officials may even pay such high costs as being dismissed. Assuming that the probability of an environmental event is $q(t)$, the present value of a local government's revenue is

$$
V=\int_{0}^{T}(1-\theta) v h(t)^{\alpha} K(t)^{\beta} E(t)^{\gamma} \mathrm{e}^{-\rho t} \mathrm{~d} t+\mathrm{e}^{-\rho T} S(K(T))-\sum_{t=0}^{T} q(t)\left(\varepsilon E^{\prime}(t)+\frac{1}{2} \chi E^{\prime}(t)^{2}\right)
$$

In the long term, if a local government's tenure is long enough, it can obtain the present value $V$ for every $T$ time, and duplicate receipts can be repeated indefinitely.

$$
\begin{aligned}
V_{\infty}=\lim _{N \rightarrow \infty} & {\left[\left(\int_{0}^{T}(1-\theta) v h(t)^{\alpha} K(t)^{\beta} E(t)^{\gamma} \mathrm{e}^{-\rho t} \mathrm{~d} t+\mathrm{e}^{-\rho T} S(K(T))-\sum_{t=0}^{T} q(t)\left(\varepsilon E^{\prime}(t)+\frac{1}{2} \chi E^{\prime}(t)^{2}\right)\right)\right.} \\
& \left.\times \frac{1-\left(1+\frac{t \mathrm{e}^{-\rho}}{T}\right)^{-N T / t}}{\left(1+\frac{t \mathrm{e}^{-\rho}}{T}\right)^{-T / t}-1}\right]
\end{aligned}
$$

For firms, from the perspective of sustainable development, regardless of how long the tenure of the local government may be, the costs due to political connections will be generated, and they will not be limited by the term of the local government. In the long run, firms must pay the political connection costs to maintain the profit that can be obtained. Political connection costs will change over time, and the environmental supervision of the local government will increase unceasingly, i.e., $f(t)$ tends to zero. However, in the case of an environmental event, firms will need to pay extra environmental costs.

$$
V_{F}=\int_{0}^{\infty}\left(\frac{1}{N} h(t)^{\alpha} K(t)^{\beta} E(t)^{\gamma}-P(t)\right) \mathrm{e}^{-\rho t} \mathrm{~d} t-\sum_{t=0}^{\infty} q(t)\left(\varepsilon P(t)+\frac{1}{2} \chi P(t)^{2}\right)
$$

In the long run, the present value of the local government's revenue should be equal to the present value of the corresponding proportion of all firms' income:

$$
V_{\infty}=N(1-\theta) \vee V_{F}
$$

According to function (31), $P(t)$ can be obtained at equilibrium. However, the local government does not have long-term considerations; thus, $E^{\prime}(t)$ drops unceasingly. In turn, environmental performance deteriorates.

In short, both in the short term and long term and in the event of an environmental incident, political connections will lead to low environmental performance for firms. In the third section, the relation between political connections and firms' environmental performance will be demonstrated using data obtained for companies in China.

\section{Conclusions and Policy Suggestions}

Although our findings did not support our proposed hypotheses in the short term, negative effects were deter- 
mined to exist. In the long run, the influence of the relationship between local government and regulated companies should be managed to avoid malpractice and reduce its effect on the environment.

This paper suggests that the central government implement two measures to better control the potential negative influence of the relationship between local government and regulated firms on the environment. One measure is to restrict political connections, such as prohibiting retired officials from serving as the directors of regulated companies. Another measure is to establish a system for assessing local governments' environmental performance. Thus, environmental performance can be enhanced. At the local government level, the central government should change their method and index of evaluation. As suggested in the literature, "the bad consequences of environmental deterioration focus on people’s right of existence” (Daoyang Guo [29]); indeed, the guarantee of the right of existence embodies the same goal of both the local and central government. Moreover, it is also the only way to break the balance between local governments and regulated firms. However, determining how to quantify peoples' right of existence and use it as an assessment index still requires further research. According to the classification methods regarding ecosystem service value proposed by Costanza et al. [30], local ecosystem service values can be classified and evaluated based on different ecosystem areas and ecosystem service values per unit area.

\section{Acknowledgements}

This study is supported by the National Natural Science Foundation of China (No. 71102163), Special Financial Grant from China Postdoctoral Science Foundation (No. 2012T50502), and China Postdoctoral Science Foundation (No. 2011M500977).

\section{References}

[1] Zhou, L. (2008) The Local Government in Transition: Official Incentive and Governance. Oversea Publishing House, Shanghai.

[2] Li, Y.F., Li, X.F. and Cai, T. (2009) The Economic Analysis on Government Behavior's Externality. Economic Science Press, Beijing.

[3] Li, H.L. (2008) The Analysis of China's Local Government Environmental Regulation Difficult Problem and Countermeasure Mechanism. Doctoral Dissertation of East China Normal University.

[4] Zhang, Z.H. (2010) Reducing the Environmental Regulatory Capture Countermeasure Research. Academic Exchange, 2, 74-77.

[5] Zhou, Y.D. (2004) Interest Groups Theory. Journal of Anhui University (Philosophy \& Social Sciences), 7, $106-111$.

[6] Roberts, B.E.A. (1990) Dead Senator Tells No Lies: Seniority and the Distribution of Federal Benefits. American Journal of Political Science, 34, 31-58. http://dx.doi.org/10.2307/2111510

[7] Fisman, R. ( 2001) Estimating the Value of Political Connections. American Economic Review, 91, 1095-1102. http://dx.doi.org/10.1257/aer.91.4.1095

[8] Hellman J., Jones, G. and Kaufmann, D. (2003) Seize the State, Seize the Day: State Capture and Influence in Transition Economies. Journal of Comparative Economics, 31, 751-773. http://dx.doi.org/10.1016/j.jce.2003.09.006

[9] Johnson, S. and Mitton T. (2003) Cronyism and Capital Controls: Evidence from Malaysia. Journal of Financial Economics, 67, 351-382. http://dx.doi.org/10.1016/S0304-405X(02)00255-6

[10] Faccio, M. (2006) Politically Connected Firms. American Economic Review, 96, 369-386. http://dx.doi.org/10.1257/000282806776157704

[11] Goldman, E., Rocholl, J. and So, J. (2006) Does Political Connectedness Affect Firm Value? University of North Carolina at Chapel Hill, Chapel Hill.

[12] Claessens, E., Feijen, E. and Laeven, L. (2008) Political Connections and Preferential Access to Finance: The Role of Campaign Contributions. Journal of Financial Economics, 88, 554-580. http://dx.doi.org/10.1016/j.jfineco.2006.11.003

[13] Dombrovsky, V. (2008) Do Political Connections Matter? Firm-Level Evidence form Latvia. Stockholm School of Economics in Riga and Baltic International Centre for Economic Policy Studies.

[14] Pan, H.B., Xia, X.P. and Yu, M.G. (2008) Government Intervention, Political Connections and the Mergers of Local Government-Controlled Enterprises. Economic Research Journal, 4, 41-52.

[15] Sapienza, P. (2004) The Effects of Government Ownership on Bank Lending. Journal of Financial Economics, 72, 357-384. http://dx.doi.org/10.1016/j.jfineco.2002.10.002 
[16] Khwaja, A.I. and Mian, A. (2005) Do Lenders Favor Politically Connected Firms? Rent Seeking in an Emerging Financial Market. Quarterly Journal of Economics, 120, 1371-1411. http://dx.doi.org/10.1162/003355305775097524

[17] Dinc, I.S. (2005) Politicians and Banks: Political Influences on Government-Owned Banks in Emerging Markets. Journal of Financial Economics, 77, 453-479. http://dx.doi.org/10.1016/j.jfineco.2004.06.011

[18] Fan, J.P.H., Rui, M.O. and Zhao, M. (2006) Rent Seeking and Corporate Finance: Evidence from Corruption Cases. The Chinese University of Hong Kong, Hong Kong.

[19] Hu, X.Y. (2006) Private Entrepreneur's Political Identity and the Convenience of Private Enterprises-Taking Top100 Private Companies in Zhejiang Province as Examples. Management World, 5, 107-113.

[20] Boubakri, M., Cosset, J.C. and Saffar, W. (2008) Political Connections of Newly Privatized Firms. Journal of Corporate Finance, 14, 654-673. http://dx.doi.org/10.1016/j.jcorpfin.2008.08.003

[21] Dewenter, K.L. and Malatesta, P.H. (2001) State-Owned and Privately Owned Firms: An Empirical Analysis of Profitability, Leverage and Labor Intensity. American Economic Review, 91, 320-334. http://dx.doi.org/10.1257/aer.91.1.320

[22] Chen, D.H., Fan, J.P.H. and Wong, T.J. (2004) Politically-Connected CEOs, Corporate Governance and Post-IPO Performance of China's Newly Partially Privatized Firms. Hong Kong University of Science and Technology, Hong Kong.

[23] Bertrand, M., Kramarz, F., Schoar, A., et al. (2006) Politicians, Firms and Political Business Cycle: Evidence from France. University of Chicago, Chicago.

[24] Chang, E.C. and Wong, S.M.L. (2004) Political Control and Performance in China’s Listed Firms. Journal of Comparative Economics, 32, 617-636. http://dx.doi.org/10.1016/j.jce.2004.08.001

[25] Cheung, Y.L., Jing, L.H., Raghavendra, R.P., et al. (2005) Guanxi, Political Connections and Expropriation: The Dark Side of State Ownership in Chinese Listed Companies. City University of Hong Kong, Hong Kong.

[26] Aggarwal, R.K., Meschke, F. and Wang, T. (2007) Corporate Political Contribution: Investment or Agency? University of Minnesota, Minneapolis and Saint Paul.

[27] Ball, R., Kothari, S.P. and Robin, A. (2000) The Effect of Institutional Factors on Properties of Accounting Earning: International Evidence. Journal of Accounting and Economics, 17, 137-166.

[28] Wu, W.F., et al. (2010) Ownership and the Value of Political Connections. Working Paper.

[29] Guo, D.Y. (2008) The Outline of Establishment of the Second System of Accounting Reports. Accounting Learning, 4, 14-16.

[30] Coatanza, R., Arge, R., Groot, R., et al. (1997) The Value of the World’s Ecosystem Service and Nature Capital. Nature, 386, 253-260. http://dx.doi.org/10.1038/387253a0 
Scientific Research Publishing (SCIRP) is one of the largest Open Access journal publishers. It is currently publishing more than 200 open access, online, peer-reviewed journals covering a wide range of academic disciplines. SCIRP serves the worldwide academic communities and contributes to the progress and application of science with its publication.

Other selected journals from SCIRP are listed as below. Submit your manuscript to us via either submit@scirp.org or Online Submission Portal.
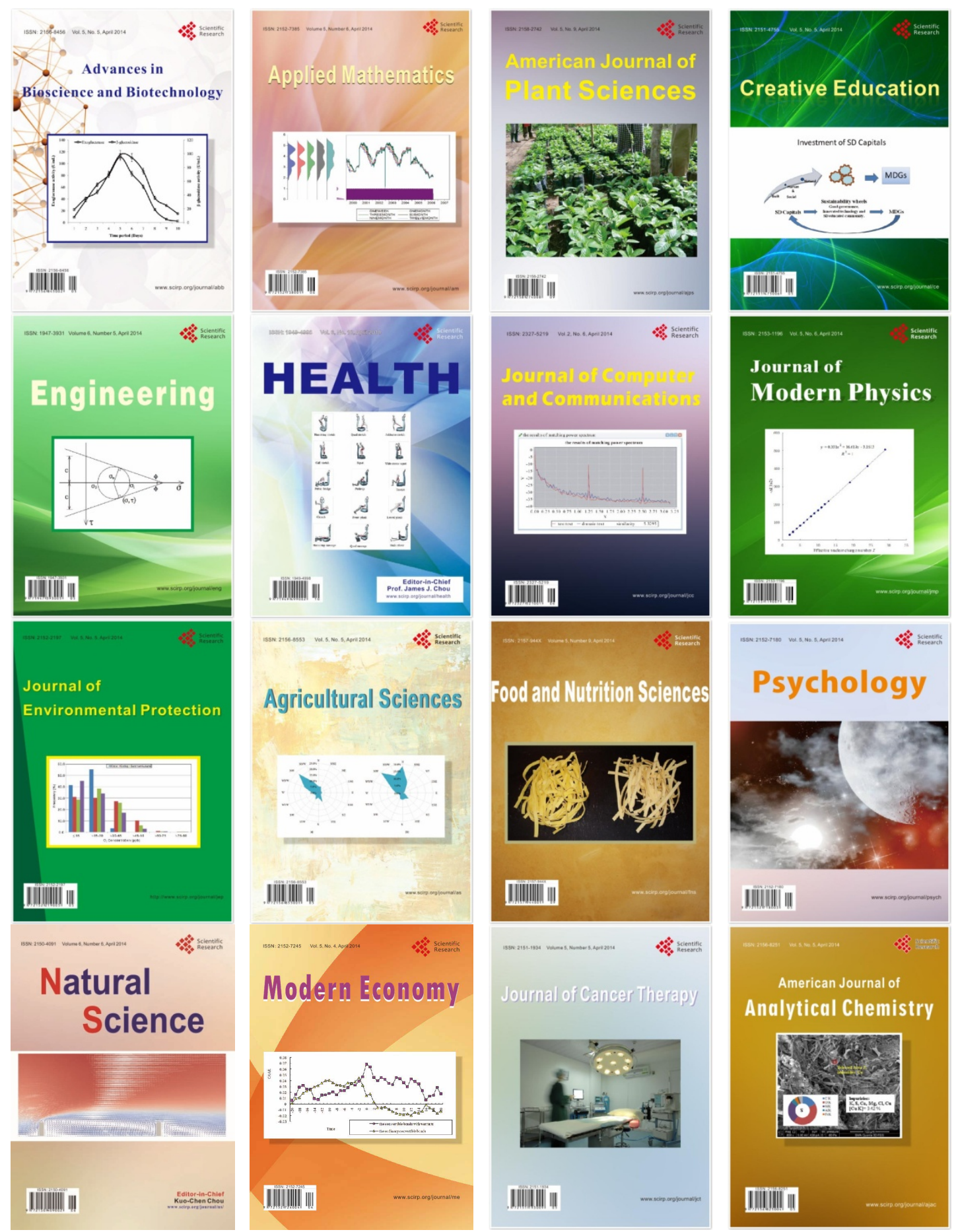